\title{
Early Onset Type 2 Diabetes Mellitus in Non-Obese Adolescents Born Small for Gestational Age
}

Hye Yeon Choi, MD, Juyoung Lee, MD, PhD, Danbi Kim, MD, Jin-Soon Suh, MD, PhD, Joong Hyun Bin, MD, Soo Young Lee, MD, and Kyoung Soon Cho, MD

Department of Pediatrics, College of Medicine, The Catholic University of Korea, Seoul, Korea

\section{ABSTRACT}

Being born small for gestational age (SGA) has been strongly associated with mortality during the perinatal period and long-term risk of metabolic syndrome, including type 2 diabetes mellitus, hypertension, hyperlipidemia, and coronary heart disease. Insulin resistance is an important factor in the development of metabolic syndrome in SGA, with several proposed hypotheses. Here, we report two cases of non-obese adolescent patients with early onset type 2 diabetes who were born SGA. Of these, one experienced catch-up growth, while the other did not. Both had a high body fat percentage at the time of diagnosis of type 2 diabetes and were diagnosed with fatty liver and hyperlipidemia before adolescence, at the age of 7 years. Early interventions for SGA are needed for healthy catch-up growth to prevent metabolic diseases in the future.

Key Words: Infant, small for gestational age; Diabetes mellitus, type 2; Metabolic syndrome; Insulin resistance; Catch-up growth

\section{서론}

부당경량아(small for gestational age)는 출생 직후 높은 영아 사망 및 이환율과 관련이 있으 며, 장기적으로 인지기능 장애, 저신장, 조기사춘기, 대사증후군, 심혈관계 질환 등의 발생 위험 도가 높다. 부당경량아의 정의에 대해서는 아직 통일된 진단 기준이 없이 여러 가지 진단 기준 이 사용되고 있는데, 신생아학회에서는 출생 시 체중 10 백분위수 미만을 부당경량아로 정의하 고 있으며, 또 다른 기준은 출생 시 체중 또는 신장이 재태연령의 평균보다 2 표준편차 이하인 경 우 또는 3 백분위수 미만인 경우로 정의하기도 한다. 우리나라에서 부당경량아 저신장 환자의 성장호르몬 치료 시 요양 급여 인정 기준은 출생 시 체중이 3 백분위수 미만인 경우이다 ${ }^{11}$. 전 세 계적으로 출생아 중 부당경량아의 비율은 8.6\%-9.6\%로 보고되고 있으며 ${ }^{2)}$, 우리나라 출생아 중 부당경량아의 비율은 5 차 국민건강영양조사를 바탕으로 한 연구에 따르면 출생 시 체중 10 백분 위수 미만을 기준으로 할 때 $11.4 \%$ 이다 ${ }^{3}$. 최근 고령 임신과 난임 시술이 많아지면서 부당경량출 생아가 증가하고 있다. 우리나라 통계청 자료에 따르면 출생체중 $2,400 \mathrm{~g}$ 이하인 출생아가 1993
Received: 9 June 2020

Revised: 26 August 2020

Accepted: 14 September 2020

Correspondence to: Kyoung Soon Cho, MD

Department of Pediatrics, Bucheon St. Mary's Hospital, College of Medicine, The Catholic University of Korea, 327 Sosa-ro, Wonmi-gu, Bucheon 14647, Korea

Tel: +82-32-340-7065

Fax: +82-32-340-2673

E-mail: soon926@catholic.ac.kr

Copyright(c)

By Korean Society of Neonatology. All right reserved.

This is an Open-Access article distributed under the terms of the Creative Commons At tribution Non-Commercial License (http:// creativecommons.org/licenses/by-nc/4.0), which permits unrestricted non-commercial use, distribution, and reproduction in any medium, provided the original work is properly cited. 
년 2.6\%에서 2015년 5.7\%로 증가하여 저출생체중아가 증가하고 있 는 추세이다 ${ }^{4)}$.

부당경량아의 장기 합병증인 대사증후군 발생은 부당경량아로 태어난 젊은 성인에서 $2.3 \%$ 로 보고되어, 정상 체중으로 태어난 경 우의 $0.4 \%$ 보다 높았다 ${ }^{5}$. 대사증후군은 복부 비만, 이상지질혈증, 고 혈당, 고혈압 등의 요소들이 군집적으로 나타나는 질환으로 동맥경 화성 심혈관계 질환과 제 2 형 당뇨병의 발병 위험을 높이게 된다. 대 사증후군의 발생에는 인슐린저항성(insulin resistance)이 중추적인 역할을 한다. 태내에서의 영양결핍이 단기적으로는 태아의 성장을 지연시키며, 장기적으로 영양이 부족한 환경에 적응하기 위한 반응 을 가져올 수 있는데, 이 적응 과정의 결과인 인슐린저항성이 부당 경량아에서 대사성 질환 발생의 주된 요소로 작용한다. 부당경량아 에서 인슐린저항성은 따라잡기 성장이 주로 일어나는 시기인 2세 이전에도 나타나나 특히 체중의 따라잡기 성장이 이루어진 경우에 더 증가한다. 부당경량아에서 인슐린저항성의 발생 기전으로 Hales 와 Barker')의 '절약체질형질가설(thrifty phenotype hypothesis)'과 $\mathrm{Neel}^{7)}$ 의 '절약유전자(thrifty genotype)' 등 열악한 자궁 내 환경 또는 유전적인 요인에 관한 몇몇 가설들이 제시되었으나 아직 그 기전이 확실하게 밝혀진 것은 아니다.

부당경량아에서 성인기에 대사성 질환의 위험도가 증가한다는 여 러 연구들이 있으나, 소아청소년 연령에서 당뇨병이나 고지혈증의 발생이 증가한다는 직접적인 증거는 아직 없다 ${ }^{8)}$. 이에 본 저자들은 부당경량아로 출생한 소아청소년에서 진단된 비비만형 제 2 형 당뇨 병 환자 2 례를 경험하여 증례를 보고하고 문헌고찰을 하고자 한다.

\section{중레}

\section{1. 증례 1}

역연령 7 세 10 개월 여아가 음모가 발생하여 내원하였다. 재태연 령 36주, 출생 체중 $1,640 \mathrm{~g}$ (<3 백분위수), 제왕절개로 출생하였다. 산모는 43세였고 쌍태임신이었으나 임신 제 1 기에 일측 태아가 사망 하였다고 하였다. 신생아기 이후 특이 병력은 없었다. 당뇨병, 고혈 압, 고지혈증 등의 가족력은 없었다. 어머니 키 $150 \mathrm{~cm}$, 아버지 키 $167 \mathrm{~cm}$ 로 중간부모신장은 $152 \mathrm{~cm}$ (3-5 백분위수)였다.

신체 진찰에서 키 $134 \mathrm{~cm}$ (90-95 백분위수), 체중 $34 \mathrm{~kg}$ (90-95 백 분위수)였고, 키와 체중으로 계산한 체질량지수(body mass index) 는 $18.9 \mathrm{~kg} / \mathrm{m}^{2}$ (75-90 백분위수)였다(Figure 1). 체성분 생체전기 저항분석법(Inbody 2.0, Biospace, Seoul, Korea)을 이용하여 체성 분을 평가하였고 체지방률은 $33.5 \%$ 였다. 성 성숙도는 Tanner 유 방 1단계, 음모 2단계였다. 혈압은 $100 / 60 \mathrm{~mm} \mathrm{Hg}$ 으로 정상 범위였 다. 혈액검사에서 혈당 $94 \mathrm{mg} / \mathrm{dL}$ 였고, aspartate aminotransferase (AST) 및 alanine aminotransferase (ALT)가 각각 $48 \mathrm{U} / \mathrm{L}$ 와 $70 \mathrm{U} / \mathrm{L}$
로 상승되어 있었고, 총 콜레스테롤 $210 \mathrm{mg} / \mathrm{dL}$ (참고치, <170), 저 밀도 콜레스테롤 $135 \mathrm{mg} / \mathrm{dL}$ (참고치, <110), 고밀도 콜레스테롤 $45 \mathrm{mg} / \mathrm{dL}$ (참고치, > 45), 중성지방 $187 \mathrm{mg} / \mathrm{dL}$ (참고치, <75)였다. 인슐린저항성의 지표인 homeostasis model assessment of insulin resistance (HOMA-IR)를 다음 공식으로 산출하여 [HOMA-IR=공 복인슐린 $(\mu \mathrm{U} / \mathrm{mL}) \times$ 공복혈당 $(\mathrm{mg} / \mathrm{dL}) / 405] 3.0$ 이상을 인슐린저항 성으로 평가하였고, HOMA-IR 값은 3.4로 인슐린저항성이 있었 다. 갑상선 기능검사를 비롯한 내분비 검사에서 triiodothyronine (T3) $156.3 \mathrm{ng} / \mathrm{dL}$ (참고치, 119-218), free thyroxine (fT4) $1.22 \mathrm{ng} /$ $\mathrm{dL}$ (참고치, 0.8-2.2), thyroid-stimulating hormone (TSH) 6.47 $\mathrm{mIU} / \mathrm{L}$ (참고치, 0.5-4.8), dehydroepiandrosterone sulfate 118.69 $\mathrm{\mu g} / \mathrm{dL}$ (참고치, 13-115), testosterone $19.93 \mathrm{ng} / \mathrm{dL}$ (참고치, 7-28), 17 -hydroxyprogesterone $0.68 \mathrm{ng} / \mathrm{mL}$ (참고치, $0.15-2.21$ ), luteinizing hormone (LH) $1.03 \mathrm{mIU} / \mathrm{mL}$ (참고치, 0.2-0.3), follicle-stimulating hormone (FSH) $<1 \mathrm{mIU} / \mathrm{mL}$ (참고치, 1.0-4.2), estradiol $<1 \mathrm{ng} / \mathrm{dL}$ (참고치, <1.5)로 모두 정상 범위였다. 방사선 검사에서 골연령은 9세였고, 복부초음파에서 지방간 소견이 확인되었다. 조 기음모발육증, 지방간, 고지혈증으로 진단하고 사춘기 진행에 대하 여 추적 관찰을 계획하였고, 대사성 질환에 대한 생활습관 개선 교육 을 시행하였다.

역연령 8세 11 개월에 유방 발달이 관찰되었고 골연령은 11세로 역연령에 비하여 골성숙 소견이 관찰되었다. 키 $145.3 \mathrm{~cm}$ (>97 백

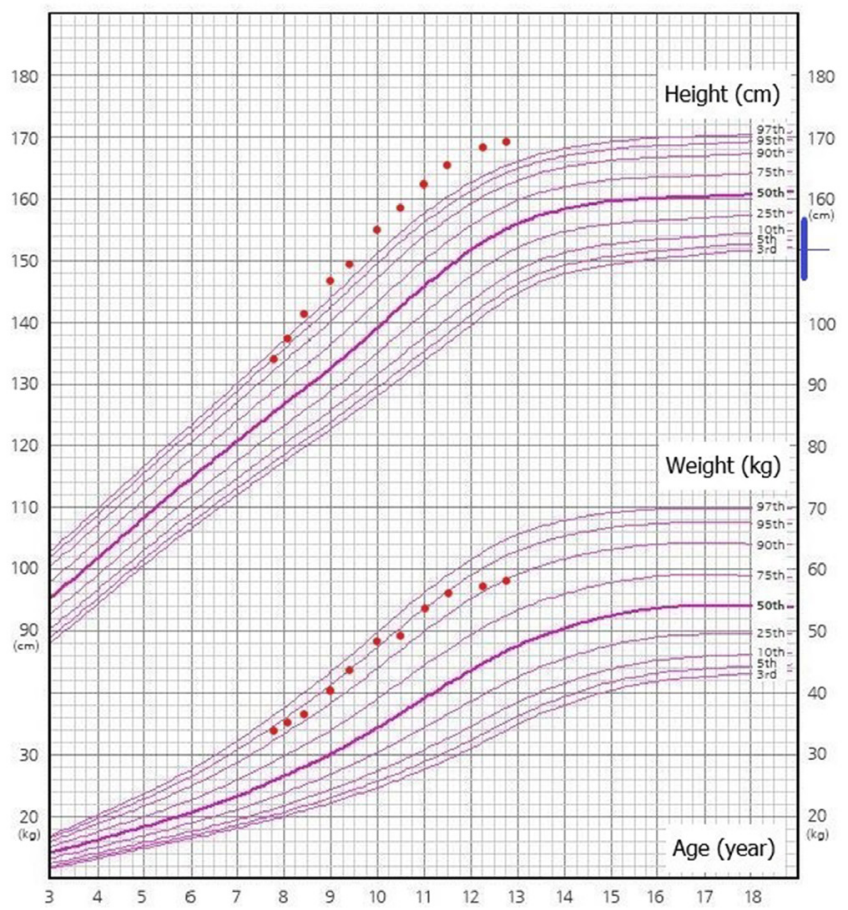

Figure 1. Growth chart of case 1. The blue vertical bar represents the target height range with the median representing mid-parental height (MPH). Target height range $=\mathrm{MPH} \pm 5 \mathrm{~cm}$. 
분위수), 체중 $40 \mathrm{~kg}$ (90-95 백분위수), 체질량지수 $18.95 \mathrm{~kg} / \mathrm{m}^{2}$ (75-90 백분위수)였다. 성선자극호르몬 자극검사에서 사춘기 반응 을 보여 중추성 성조숙증(central precocious puberty)으로 진단하 고 1년간 성선자극호르몬분비호르몬 유사효능약제(gonadotrophin releasing hormone agonist)로 치료하였다. AST 및 ALT가 각각 42 $\mathrm{U} / \mathrm{L}$ 와 $79 \mathrm{U} / \mathrm{L}$ 로 상승되어 있었고, 총 콜레스테롤 $187.6 \mathrm{mg} / \mathrm{dL}$, 저밀 도 콜레스테롤 $123 \mathrm{mg} / \mathrm{dL}$, 고밀도 콜레스테롤 $48 \mathrm{mg} / \mathrm{dL}$, 중성지방

Table 1. Patients' Characteristics at the Time of Diagnosis of Type 2 Diabetes Mellitus

\begin{tabular}{|c|c|c|c|}
\hline Characteristic & Case 1 & Case 2 & $\begin{array}{c}\text { Reference } \\
\text { range }\end{array}$ \\
\hline Sex & Female & Male & \\
\hline Age (yr) & 11 & 13 & \\
\hline Catch-up growth & Yes & No & \\
\hline Precocious puberty & Yes & No & \\
\hline Height (cm) (percentile) & $161.9(>97)$ & $147.4(5-10)$ & \\
\hline Weight (kg) (percentile) & $53.3(90-95)$ & $36(3-5)$ & \\
\hline $\begin{array}{l}\text { Body mass index }\left(\mathrm{kg} / \mathrm{m}^{2}\right) \\
\text { (percentile) }\end{array}$ & $20.3(50-75)$ & $16.57(5-10)$ & \\
\hline Body fat $(\%)$ (percentile) & $35.6(75-85)$ & $31(75-85)$ & \\
\hline $\begin{array}{l}\text { Fat mass index }\left(\mathrm{kg} / \mathrm{m}^{2}\right) \\
\text { (percentile) }\end{array}$ & $7.24(75-90)$ & $5.14(50-75)$ & \\
\hline $\begin{array}{l}\text { Fat free mass index }\left(\mathrm{kg} / \mathrm{m}^{2}\right) \\
\text { (percentile) }\end{array}$ & $13.1(50-75)$ & $11.5(<3)$ & \\
\hline $\begin{array}{l}\text { Waist circumference }(\mathrm{cm}) \\
\text { (percentile) }\end{array}$ & 74.7 (90-95) & $85.5(90-95)$ & \\
\hline Systolic blood pressure ( $\mathrm{mmHg}$ ) & 110 & 110 & $<130$ \\
\hline $\begin{array}{l}\text { Diastolic blood pressure } \\
(\mathrm{mmHg})\end{array}$ & 70 & 65 & $<85$ \\
\hline Fasting plasma glucose $(\mathrm{mg} / \mathrm{dL})$ & 142 & 132 & $<110$ \\
\hline $\operatorname{HbAlc}(\%)$ & 7.1 & 6.5 & $<5.7$ \\
\hline Fasting C-peptide (ng/mL) & 5.05 & 3.84 & $0.4-2.2$ \\
\hline Fasting insulin $(\mu \mathrm{U} / \mathrm{mL})$ & 45 & 36.82 & $<15$ \\
\hline HOMA-IR & 15.3 & 8.3 & $<3$ \\
\hline $\operatorname{AST}(\mathrm{U} / \mathrm{L})$ & 153 & 51 & $<46$ \\
\hline $\operatorname{ALT}(\mathrm{U} / \mathrm{L})$ & 207 & 60 & $<35$ \\
\hline Total cholesterol (mg/dL) & 241 & 197 & $<170$ \\
\hline LDL-C (mg/dL) & 159 & 124 & $<110$ \\
\hline HDL-C (mg/dL) & 41 & 72 & $>45$ \\
\hline Triglyceride (mg/dL) & 229 & 163 & $<75$ \\
\hline $\mathrm{T} 3(\mathrm{ng} / \mathrm{dL})$ & 173.7 & 166.1 & $119-218$ \\
\hline fT4 (ng/dL) & 1.28 & 1.47 & $0.8-2.2$ \\
\hline $\mathrm{TSH}(\mathrm{mIU} / \mathrm{L})$ & 3.03 & 2.12 & $0.5-4.8$ \\
\hline
\end{tabular}

Abbreviations: HbAlc, hemoglobin Alc; HOMA-IR, homeostasis model assessment of insulin resistance; AST, aspartate aminotransferase; ALT, alanine aminotransferase; LDL-C, low-density lipoprotein cholesterol; HDL-C, high-density lipoprotein cholesterol; T3, triiodothyronine; fT4, free thyroxine; TSH, thyroid-stimulating hormone.
$107 \mathrm{mg} / \mathrm{dL}$ 로 지방간과 고지혈증이 지속되었다.

성선자극호르몬분비호르몬 유사효능약제 치료 종결 1년 후인 역 연령 11세에 초경을 하였다. 키 $161.9 \mathrm{~cm}$ (>97 백분위수), 체중 53.3 $\mathrm{kg}$ (90-95 백분위수), 체질량지수 $20.3 \mathrm{~kg} / \mathrm{m}^{2}$ (75 백분위수), 체지 방률 35.6\% (75-85 백분위수)였다. 이때 시행한 검사에서 당화혈색 소 $7.1 \%$ (참고치, <5.7\%)로 당뇨병이 진단되었다. 케톤산증의 증 상이 없었고, C-펩타이드 $5.05 \mathrm{ng} / \mathrm{mL}$ (참고치, 0.4-2.2)로 증가 소 견 및 항 glutamic acid decarboxylase (GAD) 항체 음성으로 확인 되어 당뇨병 분류는 제 2 형 당뇨병에 해당되었다. 갑상선 기능검사 결과 T3 $173.7 \mathrm{ng} / \mathrm{dL}$ (참고치, 119-218), fT4 $1.28 \mathrm{ng} / \mathrm{dL}$ (참고치, 0.8-2.2), TSH $3.03 \mathrm{mIU} / \mathrm{L}$ (참고치, 0.5-4.8)로 정상 범위였으며, 혈 중 AST/ALT는 이전보다 증가되었고 고콜레스테롤혈증과 고중성지 방혈증도 악화 소견을 보였다(Table 1). 경구혈당강하제인 메트포 민(metformin) 치료를 시작하였고, 생활습관 개선을 재교육하였다.

\section{2. 증례 2}

역연령 4세 6개월 남아가 저신장에 대한 검사를 위해 성장클리닉 으로 의뢰되었다. 재태연령 33주 6일, 출생 시 키 $43 \mathrm{~cm}$ (25-50 백분 위수), 체중 $1,450 \mathrm{~g}$ (<3 백분위수), 두위 $29.5 \mathrm{~cm}$ (10-25 백분위수) 로 ponderal index 1.82였고, 조기양막파열, 태아곤란으로 제왕절 개 출생하였으며, 성장 및 발달 지연에 대하여 미숙아클리닉에서 추 적 관찰 중이었다. 당뇨병, 고혈압, 고지혈증 등의 가족력은 없었다. 어머니 키 $158 \mathrm{~cm}$, 아버지 키 $172 \mathrm{~cm}$ 로 중간부모신장은 $171.5 \mathrm{~cm}$ (25-50 백분위수)였다.

신체 진찰에서 키 $95.7 \mathrm{~cm}$ (<3 백분위수), 체중 $14 \mathrm{~kg}$ (<3 백분위 수), 체질량지수 $15.29 \mathrm{~kg} / \mathrm{m}^{2}$ (25-50 백분위수)였고(Figure 2), 저신 장 이외의 특이 소견은 없었다. 골연령은 4 세에 해당되었고, insulinlike growth factor-1 (IGF-1) $143.4 \mathrm{ng} / \mathrm{mL}$ (참고치, 7.9-253.8), IGFbinding protein 3 (IGF-BP3) 2,636.02 ng/mL (참고치, 1,120-3,120) 로 정상 범위였으며 성장호르몬 자극검사에서 정상 성장호르몬 분 비를 확인하여 부당경량아의 따라잡기 성장 실패로 인한 저신장으 로 진단하였다. 치료를 권고하였으나 보호자가 원하여 경과 관찰을 하기로 하였다.

역연령 7세에 키 $114.4 \mathrm{~cm}$ (<3 백분위수), 체중 18.3 (<3 백분위 수), 체질량지수 $13.98 \mathrm{~kg} / \mathrm{m}^{2}$ (5 백분위수)였다. 성성숙도는 Tanner 고환 1단계, 음모 1단계로 사춘기 전 상태였고, 혈압은 96/64 mm $\mathrm{Hg}$ 로 정상 범위였다. 혈액검사에서 공복혈당 $97 \mathrm{mg} / \mathrm{dL}$ 였고, AST 및 ALT는 각각 $40 \mathrm{U} / \mathrm{L}, 39 \mathrm{U} / \mathrm{L}$ 였고, 총 콜레스테롤 $179 \mathrm{mg} / \mathrm{dL}$, 저밀 도 콜레스테롤 $135 \mathrm{mg} / \mathrm{dL}$, 고밀도 콜레스테롤, 중성지방 $304 \mathrm{mg} /$ dL이었다. HOMA-IR 값은 3.5로 인슐린저항성이 있었다. 복부초음 파에서 지방간이 관찰되었다. 저신장에 대하여 성장호르몬 치료를 시작하였고, 지방간, 고지혈증에 대하여 생활습관 개선을 교육하 였다. 


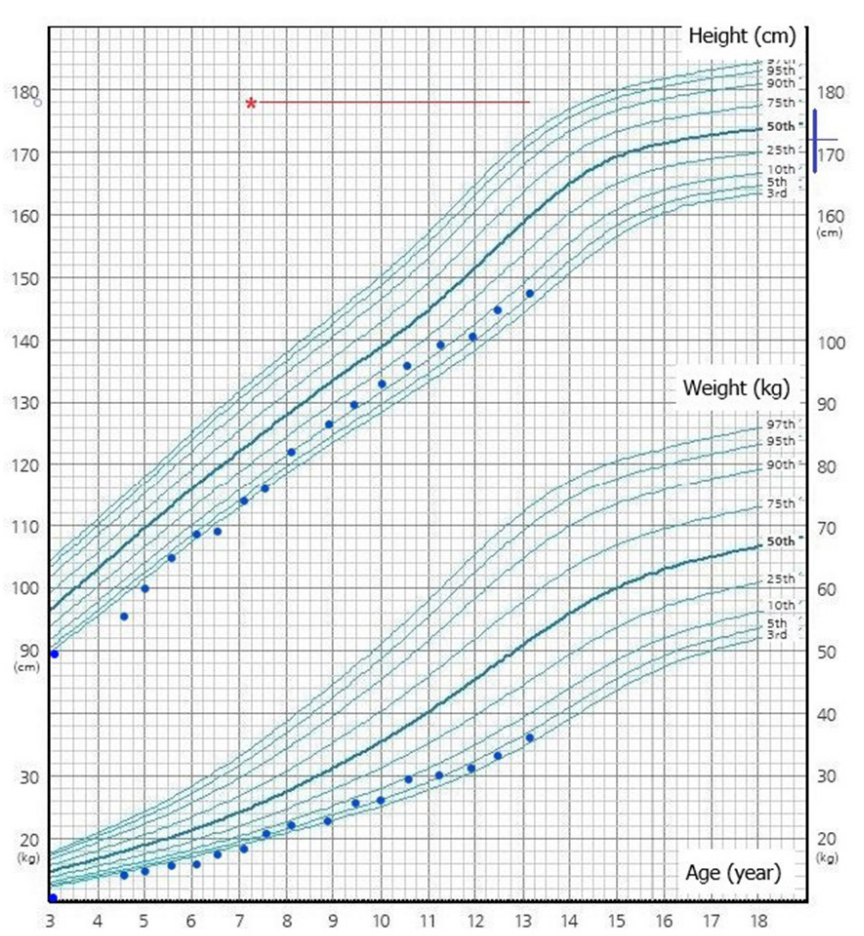

Figure 2. Growth chart of case 2. The red horizontal bar represents the growth hormone therapy duration, and the blue vertical bar represents the target height range with the median re presenting mid-parental height $(\mathrm{MPH})$. Target height range= $\mathrm{MPH} \pm 5 \mathrm{~cm}$.

역연령 10세에 키 $135.8 \mathrm{~cm}$ (10-25 백분위수), 체중 $29 \mathrm{~kg}$ (5-10 백분위수), 체질량지수 $16.6 \mathrm{~kg} / \mathrm{m}^{2}$ (5-10 백분위수)였다. 생화학검 사에서 AST/ALT는 42/31 U/L였고 총 콜레스테롤 $175.1 \mathrm{mg} / \mathrm{dL}$, 저 밀도 콜레스테롤 $87 \mathrm{mg} / \mathrm{dL}$, 고밀도 콜레스테롤 $65 \mathrm{mg} / \mathrm{dL}$, 중성지방 $191 \mathrm{mg} / \mathrm{dL}$ 로 간효소 증가, 고지혈증이 지속되었다. 당화혈색소 6\% (참고치, <5.7\%)으로 전당뇨병(prediabetes)을 추가 진단하였다. 생 활습관 개선에 대한 재교육을 시행하였다.

역연령 13세에 키 $147.4 \mathrm{~cm}$ (5-10 백분위수), 체중 $36 \mathrm{~kg}$ (3-5 백 분위수), 체질량지수 $16.57 \mathrm{~kg} / \mathrm{m}^{2}$ (5-10 백분위수), 체지방률 $31 \%$ (75-85 백분위수)였다. 이때 시행한 검사에서 당화혈색소 6.5\% (참 고치, $<5.7 \%)$ 로 당뇨병이 진단되었다. 케톤산증의 증상이 없었고, $\mathrm{C}$-펩타이드 $3.84 \mathrm{ng} / \mathrm{mL}$ (참고치, 0.4-2.2)로 상승 소견 및 항 $\mathrm{GAD}$ 항체 음성으로 확인되어 당뇨병 분류는 제 2 형 당뇨병에 해당되었 다. 갑상선 기능검사 결과 T3 $166.1 \mathrm{ng} / \mathrm{dL}$ (참고치, 119-218), fT4 $1.47 \mathrm{ng} / \mathrm{dL}$ (참고치, 0.8-2.2), TSH $2.12 \mathrm{mIU} / \mathrm{L}$ (참고치, 0.5-4.8)로 정상 범위였으며, 혈중 AST/ALT는 51/60 U/L로 증가되었고 총 콜 레스테롤 $197 \mathrm{mg} / \mathrm{dL}$, 저밀도 콜레스테롤 $124 \mathrm{mg} / \mathrm{dL}$, 고밀도 콜레 스테롤 $72 \mathrm{mg} / \mathrm{dL}$, 중성지방 $163 \mathrm{mg} / \mathrm{dL}$ 로 고콜레스테롤혈증과 고 중성지방혈증이 지속되었다(Table 1). 경구혈당강하제인 메트포민 (metformin) 치료를 시작하였고, 생활습관 개선을 재교육하였다.
고찰

소아청소년에서 비만의 유병률이 증가하면서 인슐린저항성에 의 해 발생하는 제 2 형 당뇨병이 소아청소년 연령에서도 증가하고 있 고, Search for Diabetes in Youth (SEARCH) 연구에 의하면 청소년 기 제 2 형 당뇨병의 발생은 연간 $4.8 \%$ 증가하는 추세이다 ${ }^{9}$. 본 증례 의 환자들은 체질량지수가 정상 범위이고 제 2 형 당뇨병의 가족력이 없음에도 불구하고 소아청소년 연령에서 제 2 형 당뇨병이 조기에 발 생하였다. 이에 부당경량아와 관련한 인슐린저항성이 제 2 형 당뇨병 발생의 중요한 요인으로 사료된다. 따라잡기 성장이 부당경량아의 대사성 질환 발생과 관련이 있는 것으로 알려져 있으나, 증례 2 의 경 우 따라잡기 성장에 실패하였음에도 조기에 대사성 질환이 발생하 였다. 제 2 형 당뇨병과 출생체중의 관계는 부당경량아와 부당중량아 (large for gestational age)에서 증가하는 U-shape를 보인다.

1989년 Barker 등 ${ }^{10}$ 이 영아기 저체중이 허혈성 심질환으로 인한 사망과 연관이 있음을 처음 보고하였고, 이후 부당경량아에서 제2 형 당뇨병을 비롯한 대사 질환에 이환될 위험이 증가된다는 여러 보 고들이 있었다. 부당경량아에서 대사성 질환 발생의 위험도가 증가 하는 기전은 인슐린저항성으로 설명되고 있다. Soto 등 ${ }^{11}$ 의 연구에 서는 부당경량아로 출생한 환아들에서 1 세경 이미 인슐린저항성이 관찰되었고 이것이 따라잡기 성장 및 빠른 체중 증가와 관련이 있을 것이라고 제안하였다. 그러나 다른 연구에서는 따라잡기 성장이 뚜 렷하지 않은 부당경량아에서 생후 12 개월에 인슐린저항성이 관찰 되었고 ${ }^{12}$, 적절한 따라잡기 성장이 이루어진 부당경량아에서도 적 정체중아(appropriate gestational age)와 비교했을 때 더 높은 인슐 린저항성을 보이는 것으로 나타났다. 따라서 부당경량아는 따라잡 기 성장 과정에서 인슐린저항성이 뚜렷해지지만, 출생 이전에 이미 인슐린저항성의 소질을 가지고 있는 것으로 보인다.

부당경량아에서 인슐린저항성은 영아기부터 나타나지만, 제 2 형 당뇨병, 고혈압, 고지혈증 등의 대사성 질환은 대부분 성인기에 나 타나는 것으로 알려져 있고, 소아청소년기에 대사성 질환 발생에 대 한 연구는 많지 않다. 대만에서 1996년부터 2004년까지 시행된 대 규모 코호트 연구에서는 18세 이하의 부당경량아 출생아군에서의 대사성 질환의 발생률이 대조군에 비하여 약 3 배 높았다 ${ }^{13)}$. 일본의 소아청소년 제 2 형 당뇨병 환자를 대상으로 한 역학 연구에서도 전 체 출생아 중 부당경량아의 비율이 $6.3 \%$ 인데 비하여 소아청소년기 제 2 형 당뇨병 환자에서 부당경량아의 비율은 비만형에서 $8.5 \%$, 비 비만형에서 $20.8 \%$ 로, 제 2 형 당뇨병 환자에서 부당경량아의 비율이 높고 특히 비비만형에서 그 비율이 더 높았다 ${ }^{14)}$. 그러나 우리나라 국 민건강영양조사의 자료를 이용한 연구에서는 소아청소년 연령에서 출생체중에 따른 대사증후군 유병률의 차이가 뚜렷하지 않았닿․

부당경량아에서 인슐린저항성은 과도한 체지방과 관련이 있다. 본 증례의 환자들도 체질량지수는 정상 범위이나 체지방률이 높아 
마른 비만(thin-fat baby, normal weight obesity)에 해당된다. 미국 의 2-47개월 영유아를 대상으로 한 연구에서는 부당중량아에 비하 여 부당경량아에서 체지방률이 높게 나타났달. 중국에서 따라잡기 성장이 이루어진 부당경량아와 적정체중아를 2 세부터 4 세까지 추 적 관찰한 결과, 부당경량아는 2 세경 키와 체중의 따라잡기 성장이 완료되었으며 2-4세 사이 총 체지방률 및 복부지방률이 적정체중아 보다 많아져 이 시기에 인슐린저항성이 발생하는 것으로 추정된다 15) 청소년과 성인을 대상으로 한 연구에서도 체지방 증가와 부당경 량아의 관련성이 관찰되었다 ${ }^{5}$. 체성분과 대사증후군의 관계에 대해 중국에서 청소년과 성인 32,036 명을 대상으로 한 대규모 연구에서 는, 체지방률이 $5 \%$ 증가함에 따라 남성의 $44.6 \%$, 여성의 $53.4 \%$ 에서 대사증후군의 위험도가 상승하며, 허리-엉덩이 둘레비(waist-to-hip ratio)가 5\% 증가함에 따라 남녀 모두에서 대사증후군 위험도가 약 2 배 상승하는 것으로 확인되었다 ${ }^{16)}$. 따라서 부당경량아에서 높은 체 지방률 및 복부지방률이 인슐린저항성을 증가시켜 대사증후군의 위험을 높이는 것으로 생각된다.

증례 2는 따라잡기 성장에 실패한 부당경량아의 저신장으로, 7 세 부터 성장호르몬 치료 중 제 2 형 당뇨병이 진단되었다. 부당경량아 의 10\%-20\%가 따라잡기 성장에 실패하여 성인기까지 계속 저신장 으로 남기 때문에 이에 대하여 성장호르몬 치료가 필요하다. 미국 식품의약국(Food and Drug Administration)에서는 2001년 부당경 량아에서 성장호르몬 치료에 대한 적응증을 승인하였으며, 우리나 라에서는 2008년 적응증을 인정받아 2014년부터 보험급여를 인정 하고 있다. 성장호르몬의 항인슐린 효과로 혈당 상승의 부작용이 나타날 수 있어 성장호르몬 치료 시 혈당에 대한 모니터가 필요하 다. 그러나 성장호르몬이 혈당 상승에 미치는 효과는 경미하고 일 과성인 것으로 보이며, 저신장에 대해 성장호르몬 치료를 받은 부 당경량아에서 근육량은 증가하고 체지방은 감소되어 체성분이 개 선되었고, 혈압과 지질대사에도 긍정적인 영향을 미치는 것으로 보 고되었다 ${ }^{17)}$.

대사성 질환의 고위험군인 부당경량아의 건강한 성장을 위한 구 체적인 방안에 대해서는 아직 뚜렷한 지침은 없으나, 모유수유가 영 아기 체중 증가를 완만하게 하고 소아 비만을 예방하며 신경 및 인 지 발달을 촉진시킨다고 알려져 있다. 부당경량아에서 모유수유가 따라잡기 성장을 완만하게 하는 기전은 명확하게 밝혀져 있지 않으 나, 모유는 분유에 비해 열량이 낮고, 장쇄다불포화지방산과 같은 성분이 포함되어 있어 비만을 예방하고 체성분을 개선할 수 있을 것 으로 생각된다. 또한 분유수유아와 비교하여 모유수유아에서 영아 기에 체지방이 적고, 높은 인슐린 민감도와 adiponectin의 증가가 관찰되어 대사증후군의 위험도를 낮추는 데 도움이 될 수 있다 ${ }^{18)}$.

부당경량아의 따라잡기 성장에 대한 Lei 등 ${ }^{19)}$ 의 연구에 의하면 출 생 후 첫 수개월에 약 30 백분위수에 도달한 후 7세까지 50 백분위 수에 도달하는 경우 성장 발달 및 대사성 질환에 좋은 예후를 보였
다. Kesavan과 Devaskar ${ }^{20}$ 는 부당경량출생아의 건강 관리에 대하 여 (1) 생후 1 년 동안 3 개월마다, 이후 6 개월마다 키와 체중을 측정 하여 평가하고, (2) 매년 혈압을 측정하고, (3) 대사증후군과 심혈관 질환을 예측하는 방향으로 성장 패턴을 자세하게 관찰하고, (4) 체 질량지수 및 공복 혈당과 지질을 자세하게 모니터링하고, (5) 조기 부터 건강한 생활 습관에 대한 교육을 시행할 것을 제시하였다.

부당경량아로 출생한 소아청소년에서 조기에 발생한 비비만형 제2형 당뇨병 2례를 경험하여 이를 보고한다. 향후 부당경량아의 대사적 문제에 대한 대규모 연구를 통하여 정상 성장 발달을 이루고 대사성 질환을 예방할 수 있는 건강 관리에 대한 지침이 필요할 것 으로 사료된다.

\section{ARTICLE INFORMATION}

\section{Ethical statement}

This study was approved by the Institutional Review Board of Bucheon St. Mary's Hospital (HC20ZASI0061). Informed consent was waived by the board.

\section{Conflicts of interest}

No potential conflict of interest relevant to this article was reported.

\section{Author contributions}

Conception or design: H.Y.C., K.S.C.

Acquisition, analysis, or interpretation of data: H.Y.C., J.L., D.K., J.S.S., J.H B., S.Y.L.

Drafting the work or revising: H.Y.C., K.S.C.

Final approval of the manuscript: K.S.C.

\section{ORCID}

Hye Yeon Choi https://orcid.org/0000-0003-3822-7131

Kyoung Soon Cho https://orcid.org/0000-0002-0212-0992

\section{Acknowledgments}

None

\section{REFERENCES}

1. Health Insurance Review and Assessment Service. Insurance Accreditation Standards [Internet]. Wonju: Health Insurance Review and Assessment Service; 2019 [cited 2020 Oct 31]. Avail 
able from: https://www.hira.or.kr/main.do.

2. Hediger ML, Overpeck MD, Kuczmarski RJ, McGlynn A, Maurer KR, Davis WW. Muscularity and fatness of infants and young children born small- or large-for-gestational-age. Pediatrics 1998;102:E60.

3. Cho WK, Jung IA, Suh BK. Current growth status and metabolic parameters of Korean adolescents born small for gestational age: results from the Korea National Health and Nutrition Examination Surveys (KNHANES) 2010-2011. Pediatr Int 2014; 56:3448.

4. Kim HE, Song IG, Chung SH, Choi YS, Bae CW. Trends in birth weight and the incidence of low birth weight and advanced maternal age in Korea between 1993 and 2016. J Korean Med Sci 2019;34:e34.

5. Jaquet D, Deghmoun S, Chevenne D, Collin D, Czernichow P, Levy-Marchal C. Dynamic change in adiposity from fetal to postnatal life is involved in the metabolic syndrome associated with reduced fetal growth. Diabetologia 2005;48:849-55.

6. Hales CN, Barker DJ. Type 2 (non-insulin-dependent) diabetes mellitus: the thrifty phenotype hypothesis. Diabetologia 1992; 35:595-601.

7. Neel JV. Diabetes mellitus: a "thrifty" genotype rendered de trimental by "progress"? Am J Hum Genet 1962;14:353-62.

8. Hwang IT. Long-term care, from neonatal period to adulthood, of children born small for gestational age. Clin Pediatr Endo crinol 2019;28:97-103.

9. Jensen ET, Dabelea D. Type 2 diabetes in youth: new lessons from the SEARCH study. Curr Diab Rep 2018;18:36.

10. Barker DJ, Winter PD, Osmond C, Margetts B, Simmonds SJ. Weight in infancy and death from ischaemic heart disease. Lancet 1989;2:577-80.

11. Soto N, Bazaes RA, Pena V, Salazar T, Avila A, Iniguez G, et al. Insulin sensitivity and secretion are related to catch-up growth in small-for-gestational-age infants at age 1 year: results from a prospective cohort. J Clin Endocrinol Metab 2003;88:3645-50.
12. Giapros V, Vavva E, Siomou E, Kolios G, Tsabouri S, Cholevas $\mathrm{V}$, et al. Low-birth-weight, but not catch-up growth, correlates with insulin resistance and resistin level in SGA infants at 12 months. J Matern Fetal Neonatal Med 2017;30:1771-6.

13. Huang YT, Lin HY, Wang $\mathrm{CH}$, Su BH, Lin CC. Association of preterm birth and small for gestational age with metabolic outcomes in children and adolescents: a population-based cohort study from Taiwan. Pediatr Neonatol 2018;59:147-53.

14. Urakami T, Kuwabara R, Habu M, Okuno M, Suzuki J, Takahashi S, et al. Clinical characteristics of non-obese children with type 2 diabetes mellitus without involvement of $\beta$-cell autoimmunity. Diabetes Res Clin Pract 2013;99:105-11.

15. Liu C, Wu B, Lin N, Fang X. Insulin resistance and its association with catch-up growth in Chinese children born small for gestational age. Obesity (Silver Spring) 2017;25:172-7.

16. Xu T, Liu J, Liu J, Zhu G, Han S. Relation between metabolic syndrome and body compositions among Chinese adolescents and adults from a large-scale population survey. BMC Public Health 2017;17:337.

17. Sas T, Mulder P, Hokken-Koelega A. Body composition, blood pressure, and lipid metabolism before and during long-term growth hormone $(\mathrm{GH})$ treatment in children with short stature born small for gestational age either with or without GH deficiency. J Clin Endocrinol Metab 2000;85:3786-92.

18. De Zegher F, Sebastiani G, Diaz M, Gomez-Roig MD, LopezBermejo A, Ibanez L. Breast-feeding vs formula-feeding for infants born small-for-gestational-age: divergent effects on fat mass and on circulating IGF-I and high-molecular-weight adiponectin in late infancy. J Clin Endocrinol Metab 2013;98: 1242- 7.

19. Lei X, Chen Y, Ye J, Ouyang F, Jiang F, Zhang J. The optimal postnatal growth trajectory for term small for gestational age babies: a prospective cohort study. J Pediatr 2015;166:54-8.

20. Kesavan K, Devaskar SU. Intrauterine growth restriction: post natal monitoring and outcomes. Pediatr Clin North Am 2019; 66:403-23. 